\title{
Changes in Major Element Hydrochemistry of the Pecos River in the American Southwest Since 1935
}

\author{
Fasong Yuan \\ Cleveland State University, f.yuan06@csuohio.edu \\ Seiichi Miyamoto \\ Texas A \& M University \\ Shilpa Anand \\ Texas A \& M University
}

Follow this and additional works at: https://engagedscholarship.csuohio.edu/scibges_facpub

Part of the Biology Commons

How does access to this work benefit you? Let us know!

\section{Publisher's Statement}

NOTICE: this is the author's version of a work that was accepted for publication in Applied Geochemistry. Changes resulting from the publishing process, such as peer review, editing, corrections, structural formatting, and other quality control mechanisms may not be reflected in this document. Changes may have been made to this work since it was submitted for publication. A definitive version was subsequently published in Applied Geochemistry, [22, 8, (August 2007)] DOI: 10.1016/j.apgeochem.2007.03.036

\section{Recommended Citation}

Yuan F, Miyamoto S, Anand S. 2007. Changes in major element hydrochemistry of the Pecos River in the American Southwest since 1935. Appl Geochem. 22(8):1798-813.

This Article is brought to you for free and open access by the Biological, Geological, and Environmental Sciences Department at EngagedScholarship@CSU. It has been accepted for inclusion in Biological, Geological, and Environmental Faculty Publications by an authorized administrator of EngagedScholarship@CSU. For more information, please contact library.es@csuohio.edu. 


\title{
Changes in major element hydrochemistry of the Pecos River in the American Southwest since 1935
}

\author{
Fasong Yuan ${ }^{\text {a,b,*, }}$, Seiichi Miyamoto ${ }^{\text {a }}$, Shilpa Anand ${ }^{\text {a }}$
}

${ }^{\text {a }}$ Agricultural Research and Extension Center, Texas A\&M University, 1380 A\&M Circle, El Paso, TX 79927, USA

b Department of Biological, Geological, and Environmental Sciences, Cleveland State University, 2121 Euclid Avenue, Cleveland, $\mathrm{OH} 44115$, USA

\section{Introduction}

The Pecos River has been the subject of investigation for more than a century since the early stud- ies by Harrington (1885). The water chemistry of the Pecos River was first described in a biennial report of the State Engineer of New Mexico (Howard and White, 1938), which was based on chemical composition data of water samples taken in an extremely wet year (July 1937-June 1938). Their results indicated steep increases in dissolved salt load of the river near the Artesia and Malaga Bend areas (Fig. 1). They postulated that the underlying 
salt beds at the base of the Rustler formation were the primary salt sources of the subsurface brine seeping into the river near the Malaga Bend. This led to several salinity alleviation projects at Malaga Bend that attempted to reduce the amount of the brine seeping into the Pecos River by lowering the hydraulic head of the brine aquifer (Hale et al., 1954; Havens and Wilkins, 1980). The idea of pumping deep brine into a nearby "isolated" depression has been proved to be costly and unsuccessful due to leakage from the depression (Havens and Wilkins, 1980).

Dryland rivers are characterized by long period with low flow, high hydrologic diversity, and extremely large flow variability on seasonal, interannual and decadal timescales (Davies et al., 1996; Knigh- ton and Nanson, 1997; McMahon, 1979). In the Pecos River, for example, stream discharge is on average below $10 \mathrm{~m}^{3} / \mathrm{s}$, but exceeds $1000 \mathrm{~m}^{3} / \mathrm{s}$ during some wet seasons. Seasonal variations in stream discharge are largely affected by reservoir operation, water allocation, and irrigation practices, whilst interannual and decadal changes in stream discharge appear to be associated with large-scale climatic phenomena such as the El Niño Southern Oscillation (ENSO) (Rasmussen and Wallace, 1983) and the Pacific Decadal Oscillation (PDO) (Gershunov and Barnett, 1998; Gutzler et al., 2002; Mantua et al., 1997). For example, reservoirs in the upper Rio Grande Basin were at high stages when the PDO was in positive (warm) phase (1930-1946 and 1980-2001) and at low stages when the PDO was

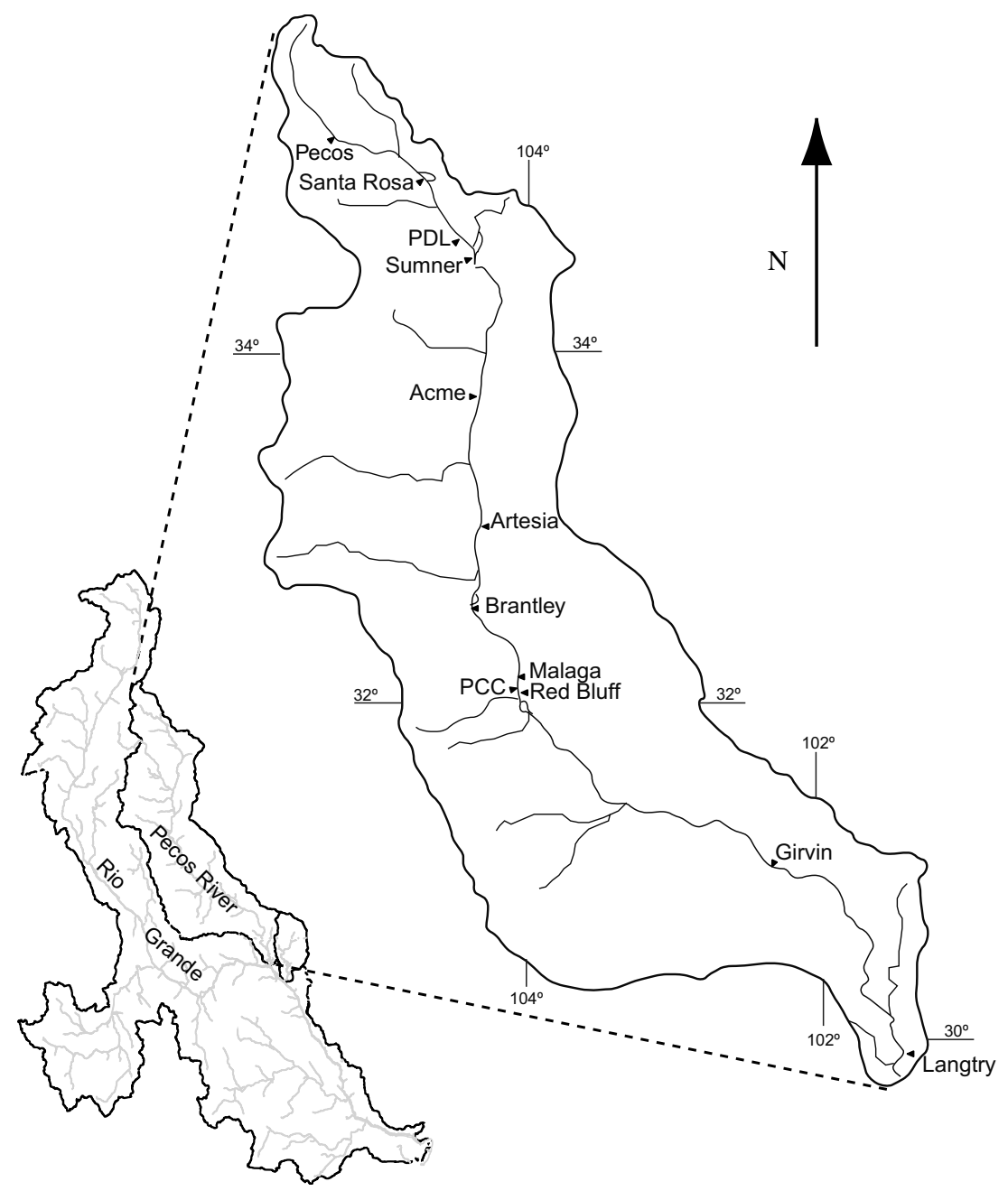

Fig. 1. Drainage map showing the Pecos River and its adjacent areas. Solid triangles indicate locations of the major gauging stations discussed. (Original base map data from the US Geological Survey). 
in negative (cold) phase (1947-1978). Such largescale climatic oscillations are believed to be the dominant sources of long-term variations in river chemistry of this region (Yuan and Miyamoto, 2004).

Major ion concentrations of river waters are usually negatively correlated with stream discharge. During dry periods, perennial dryland rivers commonly receive baseflow fed primarily by shallow groundwater and major ions derived from parent bedrocks are usually concentrated due in part to evaporative concentration occurring in rooted, unsaturated soils. During wet seasons, dryland rivers receive snowmelt from winter storms and/or runoff from local monsoonal rainfall and thus major ion concentrations are relatively low, because of the dilution effect of the meteoric waters. An analysis of spatial relationships of the total dissolved solids (TDS) concentration and discharge further suggests that evaporative concentration and freshwater dilution are the prevailing processes controlling water chemistry of the Pecos River (Yuan and Miyamoto, 2005).

Understanding long-term, large-scale variability in river water chemistry is increasingly important and commonly needed to develop water resources management strategies upon changing climate. Using existing stream flow and water chemical composition records, Yuan and Miyamoto (2004) showed a negative correlation between $\mathrm{Cl}$ concentration in the upper Rio Grande (El Paso, Texas) and the PDO index. However, there exists an intriguing relationship between the PDO index and $\mathrm{Cl}$ concentration in the lower Rio Grande (Amistad and Falcon, Texas), in which some $\mathrm{Cl}$ concentration maxima coincide with maxima in the PDO index and others coincide with minima in the PDO index. The causes of this complicated relationship have not been fully explored.

The Pecos River, a major tributary to the lower Rio Grande, usually contributes less than $10 \%$ of water, but more than $20 \%$ dissolved solids to the lower Rio Grande (Yuan and Miyamoto, 2004). In this paper, stream flow and water chemical composition records from the Pecos River back to 1935 are examined to better understand how stream chemistry changes over time and what the role of agriculture practices is in salt export.

\section{Pecos River basin}

The Pecos River arises in the southern slope of the Sangre de Cristo Mountains that are the south- ern extension of the Rocky Mountains. It cuts deep into inaccessible terrains with a rapid stream flow until it reaches the western margin of the Great Plains near the town of Santa Rosa ( $\sim 1400 \mathrm{~m}$ above mean sea level). The river then flows south across eastern New Mexico and southeast across western Texas and eventually joins the Rio Grande that forms the international boundary between Mexico and Texas (Fig. 1). The Pecos River has a total length of $1480 \mathrm{~km}$, with an average slope of $\sim 1 \%$. Most of the tributaries to the Pecos River are situated on the west side of the river (Fig. 1).

The Pecos River basin has a semiarid climate. Many parts of the basin receive an average annual precipitation of $\sim 30 \mathrm{~cm}$ although mountainous headwater areas receive more than $70 \mathrm{~cm}$ (Thomas, 1963). There are basically two major meteoric water sources. One is snowmelt from winter storms in mountainous headwater regions, and the other is runoff from local, intense convective activities (thunderstorms) in the lower valley. Long-term average monthly stream discharge displays a contrasting pattern of seasonal variability between the headwater areas and the lower end of the basin (Fig. 2). The peak flow in May and June is usually associated with the snowmelt, whilst the peak flow in September and October is related to local monsoonal rainfall in the lower valley. Like many rivers in the western United States, the Pecos River has experienced a considerable reduction in stream flow due to increased irrigation demands and water impoundments upstream since the late 1930s (Fig. 3). There are several relatively small dams constructed on the river, such as Santa Rosa, Sumner,

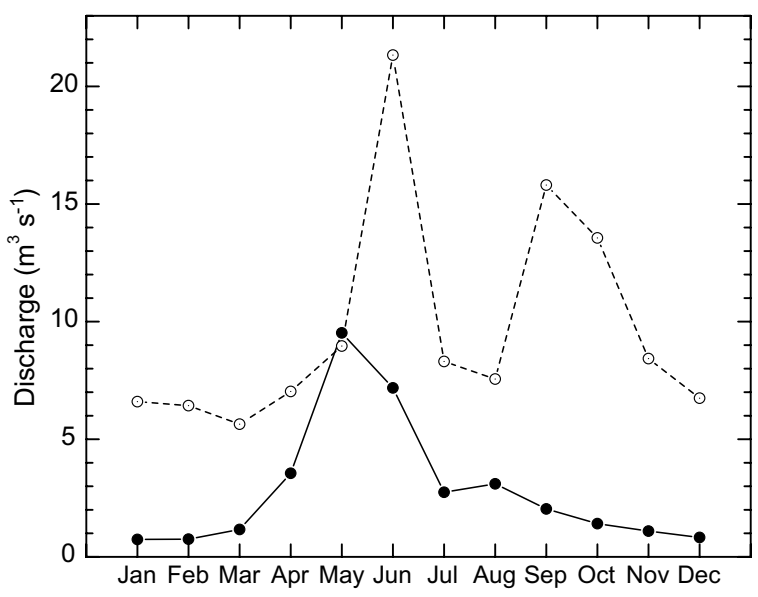

Fig. 2. Seasonal changes in stream discharge (filled circles) at Pecos, New Mexico and Langtry (open circles), Texas (average for the period 1959-2001). 


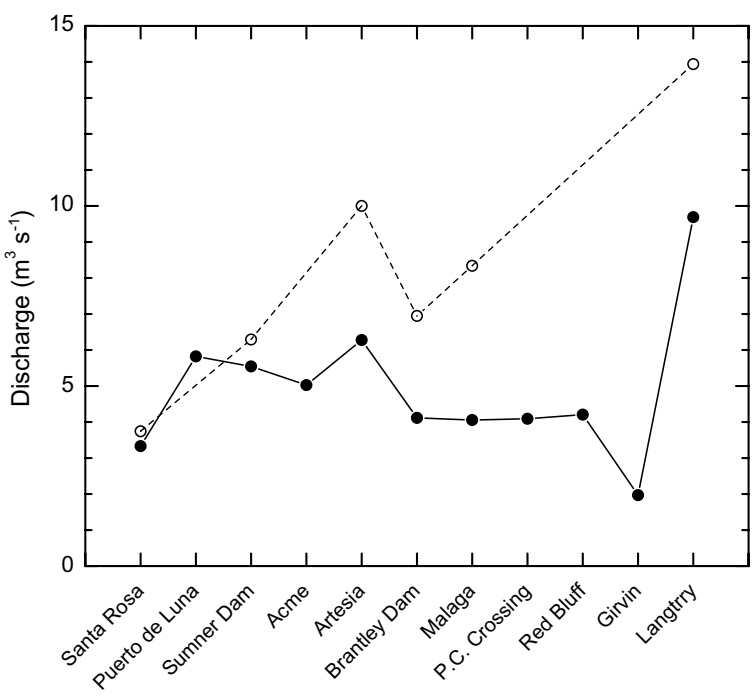

Fig. 3. Changes in stream discharge from the upper basin downward. Open circles denote average discharge for the period 1925-1937 and filled circles denote average discharge for the period 1938-2001.

Brantley, and Red Bluff. Both Sumner and Red Bluff dams were constructed in 1936/37, whereas the Santa Rosa and Brantley dams were completed in 1976 and 1988.

Geologically, the Pecos River Basin is underlain by a variety of rocks with ages from the Pre-Cambrian to Quaternary. At its headwaters, the Pecos River contains a relatively low mineral content, as the parent bedrocks consist of the Pennsylvanianaged Magdalena group (conglomerates, sandstones and limestone, etc) and the underlying Pre-Cambrian complex (granites, gneisses and schists, etc) (Sidwell, 1941). In the vicinity of Santa Rosa down to Sumner Lake, rocks exposed range in age from Triassic to Quaternary (McLemore, 1989, 1999). The Santa Rosa formation consists of conglomerates, mudstones and sandstones with gypsum pellets (Sidwell and Warn, 1953). Many "bottomless" lakes in this area are believed to be the result of evaporite dissolution that started in the Triassic and continues today (Harrington, 1957; McLemore, 1989). The Pecos River then flows along the eastern margin of the Roswell Basin and across the Delaware Basin until it reaches the Edwards Plateau of West Texas. The Roswell Basin that lies on the eastern slope of the San Andres Mountains contains Quaternary alluvial deposits and underlying San Andres limestones (Bean, 1949; Fiedler and Nye, 1933). The alluvial aquifer receives recharge from the San Andres Mountains and discharges a considerable amount of shallow groundwater to the Pecos River under natural conditions (Fiedler and Nye, 1933; Theis, 1965). The Delaware Basin is situated in the vicinity of Carlsbad and extends to Girvin. The Pecos Valley in this basin contains a wide and deep trough filled with Quaternary alluvial deposits and the underlying Castile and Salado evaporites of Permian age (Armstrong and McMillion, 1961; Ogilbee and Wesselman, 1962; Theis, 1965). Most river water depletion occurs in this section due to water diversions for irrigation, groundwater recharges, and evaporative water losses (Grozier et al., 1966; Slade et al., 2002; Thomas, 1963). In the lower Pecos Valley, the river incises the Edwards limestone. The permeable Edwards aquifer receives local intense monsoonal rainfall and discharges into the Pecos River with a short retention time (Thomas, 1963).

\section{Data and methods}

Two sets of stream monitoring data were used. One was retrieved from the National Water Information System (NWIS) of the US Geological Survey (USGS) and the other was taken from the Water Bulletin of the International Boundary and Water Commission (IBWC), United States and Mexico. Continuous daily stream readings at various gauging stations back to as early as 1905 were stored in the NWIS database. This database also contains water quality records at major gauging stations along the Pecos River back to 1959. Table 1 shows the number of chemical measurements at the major gauging stations within the last half century. Water sampling frequency varied from station to station, on average twice a month for many stations. The IBWC Water Bulletin has documented a relatively complete water chemical composition record from the Pecos River near Langtry since 1935. The original gauging station near the mouth of the river was constructed at Comstock, $9 \mathrm{~km}$ above the confluence with the Rio Grande. This gauging station was replaced by the Shumla station (30 km above the confluence), because the recording gauge installation and cableway at Comstock were destroyed by the severe flood during Hurricane Alice in June 1954 (IBWC, 1954). The Langtry station (24 km above the confluence) was operated in July 1967 (IBWC, 1967). Water sampling frequency at this site changes over the time. Prior to 1977 , chemical analyses were performed on composites made up periodically from independent water 
Table 1

Selected gauging stations from the Pecos River Basin, New Mexico and Texas ${ }^{\mathrm{a}}$

\begin{tabular}{llrc}
\hline Station number & USGS gauging station name & Chemical measurements & Period of record \\
\cline { 3 - 4 } & & 61 & Discharge \\
\hline 08378500 & Pecos River near Pecos, NM & $1919-2002$ & $1963-1973$ \\
08383000 & Pecos River at Santa Rosa, NM & 77 & $1912-1992$ \\
08383500 & Pecos River near Puerto De Luna, NM & 323 & $1959-1998$ \\
08384500 & Pecos River below Sumner Dam, NM & 1895 & $1938-2002$ \\
08386000 & Pecos River near Acme, NM & 1414 & $1912-2002$ \\
08396500 & Pecos River near Artesia, NM & 2031 & $1959-1983$ \\
08401500 & Pecos River below Brantley Dam, NM & 95 & $1905-2002$ \\
08406500 & Pecos River near Malaga, NM & 805 & $1959-1998$ \\
08407000 & Pecos River at Pierce Canyon Crossing, NM & 966 & $1971-2002$ \\
08407500 & Pecos River at Red Bluff, NM & 1083 & $1914-2002$ \\
08446500 & Pecos River near Girvin, Texas & 229 & $1959-1993$ \\
\hline
\end{tabular}

${ }^{a}$ Daily stream discharge and water quality records are from the NWIS database of the US geological survey.

samples proportional to river flow when water sample was taken (IBWC, 1967). Since then chemical analyses have been conducted on instantaneous water samples with an average sampling frequency of once a month.

Most of the chemical determinations were carried out in chemical laboratories of the US Geological Survey, using the methods described in Fishman and Friedman (1989). Most methods used prior to 1950 were gravimetric, colorimetric or titrimetric (Durum, 1978). The analytical precision (deviation) usually ranged from $2 \%$ to $10 \%$, depending on methods of determination. Major ion composition data were extracted and cross checked by comparison of the TDS concentration to the electrical conductivity. The quality of water chemical data largely depends on sampling frequency, completeness, and consistency. It is noted that significant discrepancies exist between mean flow of sampling days and grand mean flow of the entire period. Table 2 shows that the mean daily flow is usually less than the mean flow of days having chemical measurements. The values of ion concentrations measured appeared to be underestimated, as major ion concentrations in stream water are commonly inversely correlated with stream discharge. A flux-based approach was employed to estimate average major ion concentrations under average flow conditions for the period 1959-2002. In the Pecos River, robust log-linear correlations exist between major ion fluxes and stream discharge (Table 3). These empirical log-linear equations were utilized to interpolate major ion fluxes between observations (Clark et al., 2003; Hooper et al., 2001). Mean ion flux was an
Table 2

Comparison between mean daily flow and that of days with chemical data at selected gauging stations

\begin{tabular}{lllr}
\hline Gauging station & \multicolumn{2}{l}{ Mean flow $\left(\mathrm{m}^{3} / \mathrm{s}\right)$} & $(\%)$ \\
\cline { 2 - 3 } & $\begin{array}{l}\text { Daily } \\
(1959-2002)^{\mathrm{a}}\end{array}$ & $\begin{array}{l}\text { Days with } \\
\text { chemical data }\end{array}$ & \\
\hline Santa Rosa & 2.75 & 9.51 & 346 \\
Puerto & 5.34 & 5.86 & 110 \\
$\quad$ De Luna & & & \\
Sumner Dam & 5.13 & 7.03 & 137 \\
Acme & 4.39 & 7.97 & 182 \\
Artesia & 4.99 & 9.44 & 189 \\
Brantley Dam & 4.13 & 4.04 & 98 \\
Malaga & 2.55 & 4.94 & 194 \\
P.C. Crossing & 2.56 & 4.29 & 168 \\
Red Bluff & 2.67 & 5.81 & 176 \\
Girvin & 0.93 & 1.64 & 118 \\
Langtry & 7.43 & 8.76 & \\
\hline
\end{tabular}

${ }^{\text {a }}$ Except for the Brantley Dam where daily flow record started in 1971.

arithmetic mean of daily major ion fluxes for that time period which were inferred using daily stream discharge at various gauging stations. Then mean major ion concentrations $(C)$ were estimated through mean major ion flux divided by mean discharge $(Q)$.

The flux-based approach is appropriate for estimates of long-term average ion concentrations, but not for construction of a TDS concentration record. The water chemical data of the Pecos River near Langtry was used to construct a time series of TDS spanning 1935-2001. This site contains a relatively complete and reliable water chemical composition 
Table 3

Empirical log-linear relationships of stream discharge and solute flux for calculating the total dissolved salt burden ${ }^{\mathrm{a}}$

\begin{tabular}{|c|c|c|c|c|c|}
\hline Caption equation & $r$ & $n$ & Anion equation & $r$ & $n$ \\
\hline \multicolumn{6}{|l|}{ Santa Rosa, New Mexico } \\
\hline $\log ($ Ca flux $)=-0.658+0.573(\log Q)$ & 0.961 & 59 & $\log \left(\mathrm{HCO}_{3}\right.$ flux $)=-0.850+0.971(\log Q)$ & 1.000 & 6 \\
\hline $\log (\mathrm{Mg}$ flux $)=-1.547+0.581(\log Q)$ & 0.953 & 59 & $\log (\mathrm{Cl}$ flux $)=-1.642+0.498(\log Q)$ & 0.937 & 56 \\
\hline $\log (\mathrm{Na}$ flux $)=-1.611+0.640(\log Q)$ & 0.967 & 59 & $\log \left(\mathrm{SO}_{4}\right.$ flux $)=-0.280+0.477(\log Q)$ & 0.939 & 56 \\
\hline $\log (\mathrm{K}$ flux $)=-2.661+0.997(\log Q)$ & 0.997 & 56 & $\log \left(\mathrm{SiO}_{2}\right.$ flux $)=-2.015+0.823(\log Q)$ & 0.982 & 56 \\
\hline \multicolumn{6}{|l|}{ Puerto De Luna, New Mexico } \\
\hline $\log ($ Ca flux $)=-0.072+0.427(\log Q)$ & 0.857 & 294 & $\log \left(\mathrm{HCO}_{3}\right.$ flux $)=-0.868+1.025(\log Q)$ & 0.982 & 184 \\
\hline $\log (\mathrm{Mg}$ flux $)=-0.968+0.391(\log Q)$ & 0.788 & 295 & $\log (\mathrm{Cl}$ flux $)=-0.605+0.225(\log Q)$ & 0.568 & 295 \\
\hline $\log (\mathrm{Na}$ flux $)=-0.792+0.317(\log Q)$ & 0.813 & 215 & $\log \left(\mathrm{SO}_{4}\right.$ flux $)=0.405+0.317(\log Q)$ & 0.726 & 295 \\
\hline $\log (\mathrm{K}$ flux $)=-2.584+0.919(\log Q)$ & 0.953 & 215 & $\log \left(\mathrm{SiO}_{2}\right.$ flux $)=-1.813+0.89(\log Q)$ & 0.944 & 295 \\
\hline \multicolumn{6}{|l|}{ Sumner, New Mexico } \\
\hline $\log ($ Ca flux $)=-0.497+0.975(\log Q)$ & 0.989 & 138 & $\log \left(\mathrm{HCO}_{3}\right.$ flux $)=-0.879+0.973(\log Q)$ & 0.996 & 96 \\
\hline $\log (\mathrm{Mg}$ flux $)=-1.404+0.948(\log Q)$ & 0.987 & 137 & $\log (\mathrm{Cl}$ flux $)=-1.144+0.957(\log Q)$ & 0.983 & 138 \\
\hline $\log (\mathrm{Na}$ flux $)=-1.245+0.958(\log Q)$ & 0.987 & 136 & $\log \left(\mathrm{SO}_{4}\right.$ flux $)=-0.079+0.965(\log Q)$ & 0.984 & 138 \\
\hline $\log (\mathrm{K}$ flux $)=-2.553+0.99(\log Q)$ & 0.995 & 53 & $\log \left(\mathrm{SiO}_{2}\right.$ flux $)=-1.867+0.983(\log Q)$ & 0.993 & 137 \\
\hline \multicolumn{6}{|l|}{ Acme, New Mexico } \\
\hline $\log ($ Ca flux $)=-0.39+0.897(\log Q)$ & 0.982 & 759 & $\log \left(\mathrm{HCO}_{3}\right.$ flux $)=-0.937+0.997(\log Q)$ & 0.993 & 663 \\
\hline $\log (\mathrm{Mg}$ flux $)=-1.102+0.801(\log Q)$ & 0.956 & 758 & $\log (\mathrm{Cl}$ flux $)=-0.479+0.670(\log Q)$ & 0.860 & 761 \\
\hline $\log (\mathrm{Na}$ flux $)=-0.609+0.695(\log Q)$ & 0.894 & 653 & $\log \left(\mathrm{SO}_{4}\right.$ flux $)=0.101+0.865(\log Q)$ & 0.979 & 759 \\
\hline $\log (\mathrm{K}$ flux $)=-2.356+0.884(\log Q)$ & 0.988 & 239 & $\log \left(\mathrm{SiO}_{2}\right.$ flux $)=-1.859+1.014(\log Q)$ & 0.987 & 758 \\
\hline \multicolumn{6}{|l|}{ Artesia, New Mexico } \\
\hline $\log ($ Ca flux $)=-0.277+0.852(\log Q)$ & 0.977 & 1046 & $\log \left(\mathrm{HCO}_{3}\right.$ flux $)=-0.852+0.999(\log Q)$ & 0.990 & 929 \\
\hline $\log (\mathrm{Mg}$ flux $)=-0.813+0.696(\log Q)$ & 0.885 & 1046 & $\log (\mathrm{Cl}$ flux $)=0.155+0.469(\log Q)$ & 0.756 & 1061 \\
\hline $\log (\mathrm{Na}$ flux $)=-0.056+0.507(\log Q)$ & 0.789 & 901 & $\log \left(\mathrm{SO}_{4}\right.$ flux $)=0.232+0.804(\log Q)$ & 0.958 & 1046 \\
\hline $\log (\mathrm{K}$ flux $)=-1.94+0.642(\log Q)$ & 0.924 & 502 & $\log \left(\mathrm{SiO}_{2}\right.$ flux $)=-1.868+1.003(\log Q)$ & 0.970 & 1041 \\
\hline
\end{tabular}

Brantley, New Mexico

$\log ($ Ca flux $)=-0.323+0.901(\log Q)$

$\log (\operatorname{Mg}$ flux $)=-0.886+0.851(\log Q)$

0.970

0.940

0.899

$\log ($ Na flux $)=-0.286+0.843(\log Q)$

0.945

$\log \left(\mathrm{HCO}_{3}\right.$ flux $)=-0.882+0.957(\log Q)$

0.988

0.878

$\log (\mathrm{Cl}$ flux $)=-0.049+0.808(\log Q)$

$\log \left(\mathrm{SO}_{4}\right.$ flux $)=0.168+0.904(\log Q)$

0.968

$\log \left(\mathrm{SiO}_{2}\right.$ flux $)=-1.923+0.907(\log Q)$

0.952

\section{6}

56

56

56

$\log (\mathrm{K}$ flux $)=-2.221+1.002(\log Q)$

Malaga, New Mexico

$\log ($ Ca flux $)=-0.333+0.816(\log Q)$

$\log (\operatorname{Mg}$ flux $)=-0.788+0.717(\log Q)$

0.890

0.845

$\log (\mathrm{Na}$ flux $)=-0.056+0.560(\log Q)$

0.785

$\log (\mathrm{K}$ flux $)=-1.705+0.584(\log Q)$

0.883

$\log \left(\mathrm{HCO}_{3}\right.$ flux $)=-0.823+0.939(\log Q)$

0.901

0.785

776

780

488

Pierce Canyon Crossing

$\log ($ Ca flux $)=-0.296+0.834(\log Q)$

$\log (\mathrm{Mg}$ flux $)=-0.654+0.673(\log Q)$

$\log ($ Na flux $)=0.370+0.455(\log Q)$

$\log (\mathrm{K}$ flux $)=-1.202+0.542(\log Q)$

0.979

0.923

0.767

0.564

957

957

957

557

Red Bluff, New Mexico

$\log ($ Ca flux $)=-0.387+0.87(\log Q)$

$\log (\mathrm{Mg}$ flux $)=-0.769+0.73(\log Q)$

$\log (\mathrm{Na}$ flux $)=0.286+0.568(\log Q)$

$\log (\mathrm{K}$ flux $)=-1.315+0.599(\log Q)$

Girvin, Texas

$\log ($ Ca flux $)=-0.188+0.749(\log Q)$

$\log (\mathrm{Mg}$ flux $)=-0.456+0.589(\log Q)$

$\log (\mathrm{Na}$ flux $)=0.473+0.643(\log Q)$

$\log (\mathrm{K}$ flux $)=-1.329+0.789(\log Q)$
$0.801 \quad 736$

$0.729 \quad 736$

$0.635 \quad 736$

$0.486 \quad 281$

$0.930 \quad 215$

$0.774 \quad 215$

$0.865 \quad 188$

$0.926 \quad 109$ $\log \left(\mathrm{SO}_{4}\right.$ flux $)=0.191+0.769(\log Q)$

0.873

$\log \left(\mathrm{SiO}_{2}\right.$ flux $)=-1.82+0.871(\log Q)$

0.928

777

780

$\log \left(\mathrm{HCO}_{3}\right.$ flux $)=-0.81+0.951(\log Q)$

$\log (\mathrm{Cl}$ flux $)=0.582+0.448(\log Q)$

$\log \left(\mathrm{SO}_{4}\right.$ flux $)=0.273+0.764(\log Q)$

$\log \left(\mathrm{SiO}_{2}\right.$ flux $)=-1.870+0.913(\log Q)$

0.988

0.773

0.961

0.920

726

958

957

957

$\log \left(\mathrm{HCO}_{3}\right.$ flux $)=-1.000+1.088(\log Q)$

0.856

622

$\log (\mathrm{Cl}$ flux $)=0.507+0.560(\log Q)$

$\log ($ SO4flux $)=0.145+0.780(\log Q)$

$\log \left(\mathrm{SiO}_{2}\right.$ flux $)=-2.047+1.075(\log Q)$

0.644

0.737

0.916

733

589

589 $\begin{array}{lll}\log \left(\mathrm{HCO}_{3} \text { flux }\right)=-0.983+1.221(\log Q) & 0.932 & 216 \\ \log (\mathrm{Cl} \text { flux })=0.658+0.625(\log Q) & 0.813 & 225 \\ \log \left(\mathrm{SO}_{4} \text { flux }\right)=0.443+0.674(\log Q) & 0.875 & 225 \\ \log \left(\mathrm{SiO}_{2} \text { flux }\right)=-2.450+1.050(\log Q) & 0.646 & 211\end{array}$

(continued on next page) 
Table 3 (continued)

\begin{tabular}{|c|c|c|c|c|c|}
\hline Caption equation & $r$ & $n$ & Anion equation & $r$ & $n$ \\
\hline \multicolumn{6}{|l|}{ Langtry, Texas } \\
\hline $\log (\mathrm{Ca}$ flux $)=-0.858+1.003(\log Q)$ & 0.922 & 294 & $\log \left(\mathrm{HCO}_{3}\right.$ flux $)=-0.822+1.083(\log Q)$ & 0.984 & 162 \\
\hline $\log (\mathrm{Mg}$ flux $)=-1.096+0.875(\log Q)$ & 0.853 & 293 & $\log (\mathrm{Cl}$ flux $)=-0.066+0.876(\log Q)$ & 0.831 & 294 \\
\hline $\log (\mathrm{Na}$ flux $)=-0.293+0.886(\log Q)$ & 0.835 & 294 & $\log \left(\mathrm{SO}_{4}\right.$ flux $)=-0.321+0.904(\log Q)$ & 0.836 & 294 \\
\hline $\log (\mathrm{K}$ flux $)=-2.102+0.991(\log Q)$ & 0.939 & 286 & $\log \left(\mathrm{SiO}_{2}\right.$ flux $)=-1.924+1.035(\log Q)$ & 0.951 & 256 \\
\hline
\end{tabular}

${ }^{\text {a }}$ Fulx units in $\mathrm{kg} / \mathrm{s}, Q$ : discharge in $\mathrm{m}^{3} / \mathrm{s} ; r$ : correlation coefficient; $n$ : number of measurements.

record, particularly for the early part (prior to 1977) of the record in which variations in stream discharge were already taken into account during sampling and chemical measurements. Yearly volumeweighted major ion concentration was calculated using the following expression

$C=\frac{\sum_{i=1}^{n} C_{i} V_{i}}{\sum_{i=1}^{n} V_{i}}$

where $C$ is the yearly volume-weighted mean major ion concentration $\left(\mathrm{mg} \mathrm{L}^{-1}\right), C_{i}$ is the individual major ion concentration measured $\left(\mathrm{mg} \mathrm{L}^{-1}\right), V_{i}$ is the volume of stream discharge in a given month for composite samples or in a given day for instantaneous samples $\left(\mathrm{m}^{3}\right)$, and $n$ is the total number of measurements in a given year. The TDS concentration is a summation of all major ion concentrations considered.

\section{Results}

The chemical composition of the upper Pecos River is dominated by the ions of $\mathrm{Ca}^{2+}$ and $\mathrm{SO}_{4}^{2-}$, and characterized by relatively low mineral content (Table 4). There is a steep increase in salt load in the reach between Santa Rosa and Puerto De Luna which is mainly ascribed to increase in $\mathrm{CaSO}_{4}$. In contrast, the increase in salt load between Acme and Artesia is mainly attributable to an increase in $\mathrm{NaCl}$. There are salt losses and gains in the reaches above and below Malaga, which is probably associated with stream flow losses and gains. Although the annual salt load maintains the level of around 350 thousand tones in the middle basin, the TDS concentration increases substantially and exceeds $10000 \mathrm{mg} \mathrm{L}^{-1}$ at Girvin with the stream decreasing downstream. From Santa Rosa to Girvin, the river water changes from $\mathrm{Ca}$ and $\mathrm{SO}_{4}$ dominated freshwater to $\mathrm{Na}$ and $\mathrm{Cl}$ dominated saline water, but the relative abundance of $\mathrm{Mg}$ remains almost unchanged (Fig. 4). In the lower end of the river, the TDS concentration is relatively low due to the dilution effect of local freshwater inputs.

Fig. 5a shows temporal changes in TDS concentration of the Pecos River near Langtry for the period 1935-2001. The most striking feature of the TDS concentration record is that it contains a distinct pattern of decadal to multi-decadal variability. For example, the TDS concentration is generally above average $\left(2000 \mathrm{mg} \mathrm{L}^{-1}\right)$ between 1935 and 1952 and between 1985 and 1995, and below average between 1953 and 1984. More importantly, this

Table 4

Mean flow and major element hydrochemistry of the Pecos River ${ }^{\mathrm{a}}$

\begin{tabular}{|c|c|c|c|c|c|c|c|c|c|c|c|c|}
\hline $\begin{array}{l}\text { Gauging } \\
\text { station }\end{array}$ & $\begin{array}{l}\text { Flow } \\
\left(\mathrm{m}^{3} / \mathrm{s}\right)\end{array}$ & $\begin{array}{l}\mathrm{pH} \\
\text { S.U. }\end{array}$ & $\begin{array}{l}\mathrm{Ca} \\
(\mathrm{mg} / \mathrm{l})\end{array}$ & $\begin{array}{l}\mathrm{Mg} \\
(\mathrm{mg} / \mathrm{l})\end{array}$ & $\begin{array}{l}\mathrm{Na} \\
(\mathrm{mg} / \mathrm{l})\end{array}$ & $\begin{array}{l}\mathrm{K} \\
(\mathrm{mg} / \mathrm{l})\end{array}$ & $\begin{array}{l}\mathrm{HCO}_{3} \\
(\mathrm{mg} / \mathrm{l})\end{array}$ & $\begin{array}{l}\mathrm{SO}_{4} \\
(\mathrm{mg} / \mathrm{l})\end{array}$ & $\begin{array}{l}\mathrm{Cl} \\
(\mathrm{mg} / \mathrm{l})\end{array}$ & $\begin{array}{l}\mathrm{SiO}_{2} \\
(\mathrm{mg} / \mathrm{l})\end{array}$ & $\begin{array}{l}\text { TDS } \\
(\mathrm{mg} / \mathrm{l})\end{array}$ & $\begin{array}{l}\text { Salt burden } \\
\left(10^{3} \text { ton } / \mathrm{yr}\right)\end{array}$ \\
\hline Santa Rosa & 2.75 & 8.0 & 99 & 13 & 12 & 2.2 & 132 & 214 & 9 & 7 & 488 & 42 \\
\hline Puerto De Luna & 5.34 & 7.8 & 286 & 34 & 46 & 2.2 & 144 & 726 & 62 & 12 & 1312 & 221 \\
\hline Sumner Dam & 5.13 & 7.7 & 298 & 34 & 51 & 2.7 & 123 & 759 & 64 & 13 & 1345 & 218 \\
\hline Acme & 4.39 & 7.7 & 311 & 48 & 117 & 3.3 & 115 & 890 & 150 & 14 & 1649 & 228 \\
\hline Artesia & 4.99 & 7.6 & 374 & 78 & 319 & 5.3 & 140 & 1086 & 489 & 14 & 2506 & 394 \\
\hline Brantley Dam & 4.13 & 8.0 & 395 & 99 & 388 & 6.0 & 121 & 1230 & 630 & 10 & 2879 & 375 \\
\hline Malaga & 2.55 & 7.7 & 323 & 99 & 450 & 10.3 & 131 & 1006 & 743 & 12 & 2773 & 223 \\
\hline P.C. Crossing ${ }^{\text {b }}$ & 2.56 & 7.7 & 363 & 127 & 1107 & 31.7 & 139 & 1209 & 1793 & 11 & 4780 & 385 \\
\hline Red Bluff & 2.67 & 7.6 & 312 & 104 & 977 & 25.3 & 127 & 914 & 1614 & 11 & 4083 & 344 \\
\hline Girvin & 0.93 & 7.4 & 610 & 327 & 2781 & 44.4 & 118 & 2593 & 4254 & 4 & 10730 & 314 \\
\hline Langtry & 7.43 & 7.9 & 121 & 48 & 311 & 7.4 & 176 & 304 & 515 & 12 & 1494 & 350 \\
\hline
\end{tabular}

${ }^{a}$ Flow-weighted mean of the chemical data at each station during the period 1959-2002.

b Pierce Canyon Crossing, New Mexico. 
TDS concentration record shows a great deal of similarity with the PDO index, especially in the early parts (prior to 1975) of the record (Fig. 5b). This contrasts with the pattern of decadal variability in river chemistry of the upper Rio Grande, where $\mathrm{Cl}^{-}$concentration at El Paso, Texas is negatively correlated with the PDO index (Yuan and Miyamoto, 2004).

a

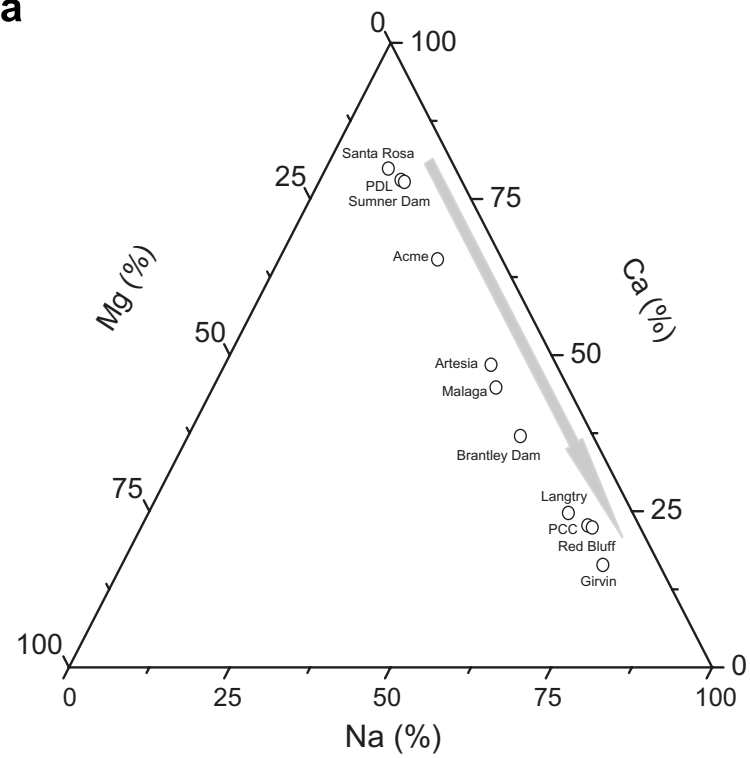

b

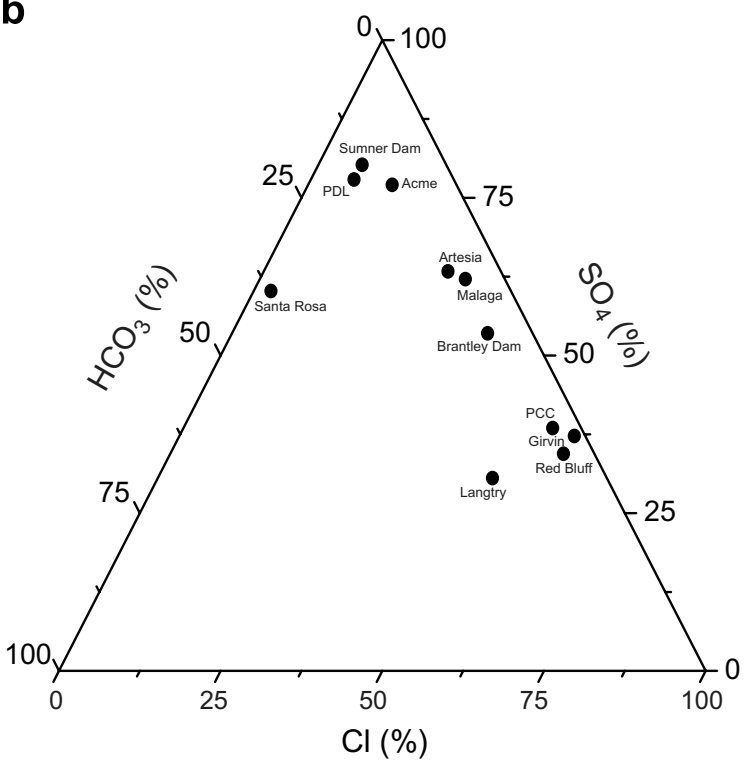

Fig. 4. Ternary plot showing changes in relative abundance of major cations (a) and major anions (b) in the Pecos River. The grey arrow denotes overall flow direction from the upper basin downward.

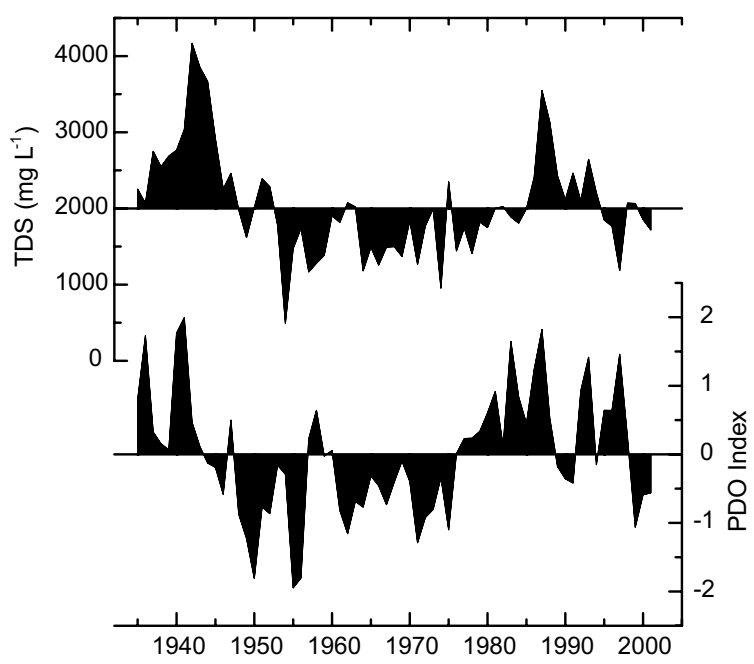

Fig. 5. Comparison of the TDS concentration with the PDO index for the period 1935-2001. The TDS record (upper panel) was derived from the measured chemical composition data from the IBWC. The time series of PDO index is the leading principal component of sea surface temperature variability in the North Pacific (Mantua et al., 1997).

\section{Discussion}

The chemical composition of stream waters inland is derived primarily from weathering of parent rocks and soils (Lasaga et al., 1994), as the airborne component is relatively insignificant compared to the bedrock weathering (Van Denburgh and Feth, 1965). In the Pecos River, most

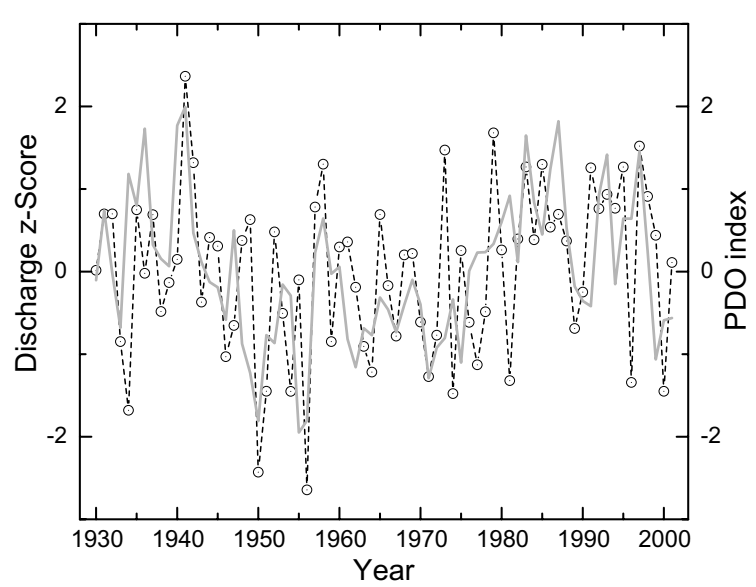

Fig. 6. Comparison of the discharge $z$-score (open circles) of Pecos, New Mexico with the PDO index (light gray curves). The $z$-score is a dimensionless quantity derived by subtracting the population mean from individual log-normally distributed discharge score (i.e., $\log Q$ ) and then dividing the difference by the standard deviation. 

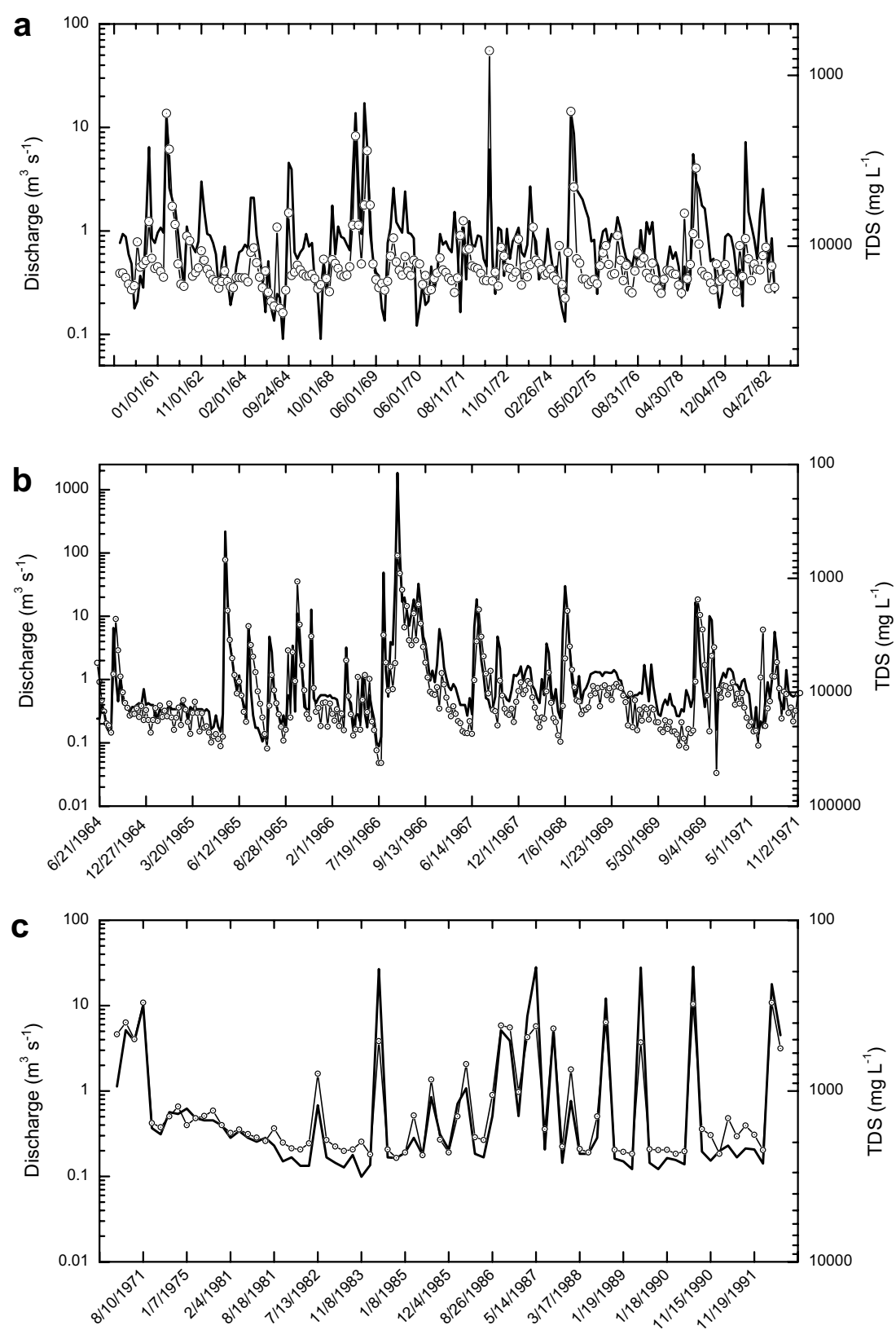

Fig. 7. Covariability of stream discharge and TDS concentration at three selected stations. (a) Girvin, Texas. (b) Pierce Canyon Crossing, New Mexico. (c) Santa Rosa, New Mexico. Solid lines correspond to numbers on the left-hand axis and open circles correspond to numbers on the right-hand axis. Note that the scale on the right-hand axis is reversed and the horizontal $(x)$ axis is not to scale.

of dissolved salts contributed to the river are from the upper valley, specifically in the reaches between Santa Rosa and Sumner and between Acme and Artesia. The dominant process is dissolution of evaporites such as gypsum, anhydrite and halite occurring in various geological formations, as witnessed by numerous sinkholes and bottomless lakes in this area (Harrington, 1957).
Stream discharge is a measure of the net water yield of a watershed, which is affected by a range of factors such as precipitation, topography, soil texture, vegetation cover and temperature, etc. The Shapiro-Wilk normality test indicates that annual stream discharge at Pecos, New Mexico is log-normally distributed $(p<0.05)$. The $z$-score of this log-normally distributed discharge is positively 

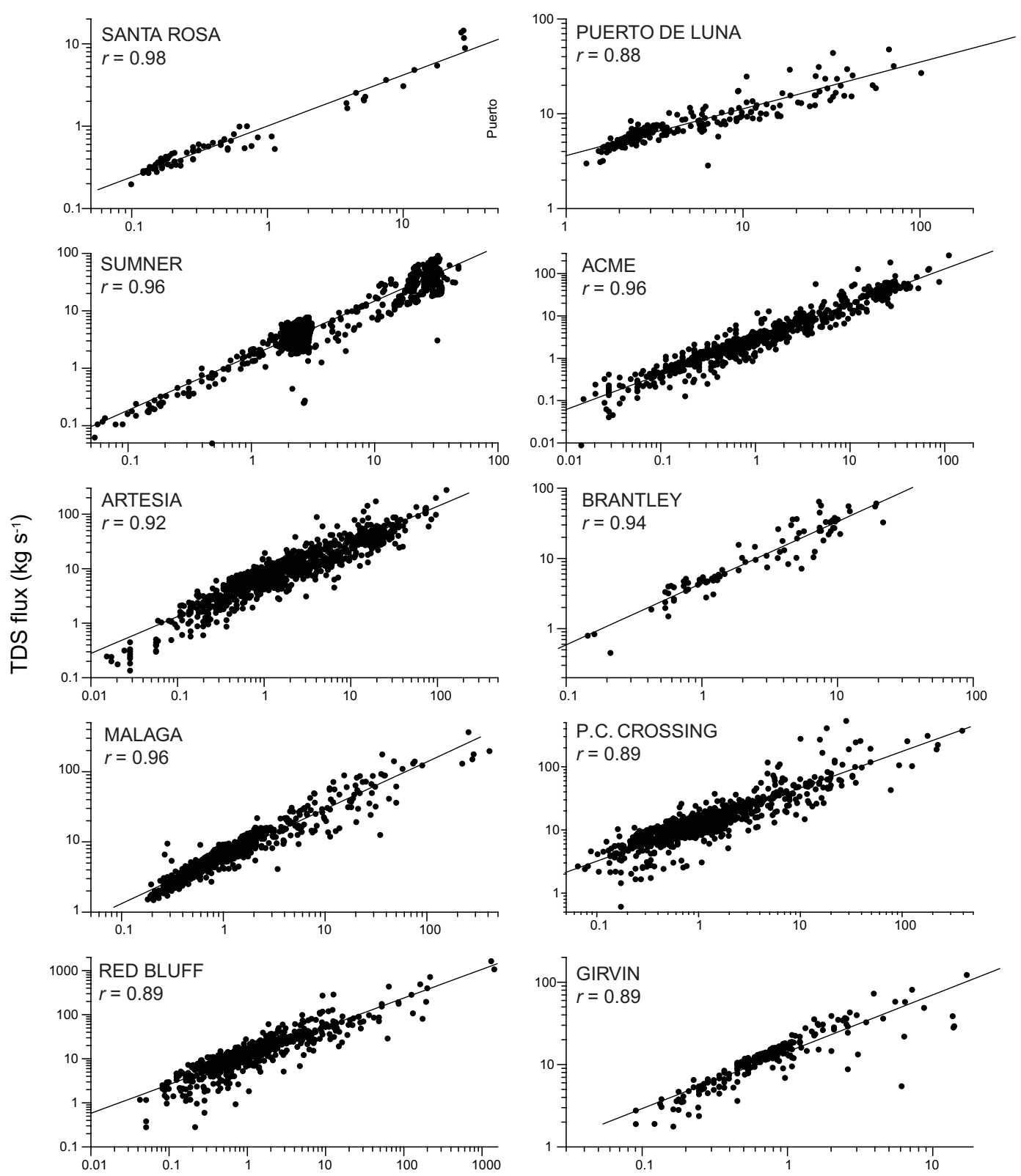

Discharge $\left(\mathrm{m}^{3} \mathrm{~s}^{-1}\right)$

Fig. 8. Plots of TDS fluxes against discharge for the 10 gauging stations indicated.

correlated with the PDO index $(r=0.45, n=72)$ (Fig. 6). This indicates that the amount of annual stream discharge of the Pecos River at the headwaters region is essentially an exponential function of the PDO index. The amount of winter precipitation in the American Southwest is related to the mean position of the atmospheric jet stream (Riehl et al., 1954; Ware and Thomson, 2000) which is essentially determined by a fairly regular pattern of high and low pressure systems over the northern portions of the North Pacific (Mantua et al., 1997). For example, a warming of the eastern margin coincides with a cooling of the central gyre, a lowering of sea level pressure (SLP) over the North Pacific and a heightening of SLP over the western US (Linsley et al., 2000; Mantua et al., 1997). This pattern of ocean-atmosphere covariability recurs every 20-30 a and forms the PDO. 
Fig. 7 shows log-linear correlations between stream discharge and TDS concentration in the Pecos River at three selected stations. The TDS concentration is overall negatively correlated to stream discharge, but the correlation decreases from the upper basin downward. Specifically, the correlation coefficient $\left(r^{2}\right)$ decreases from 0.90 at Santa Rosa to 0.67 at Pierce Canyon Crossing to 0.44 at Girvin. Such log-linear correlations have been identified in many river systems worldwide (Walling and Webb, 1983; Yuan and Miyamoto, 2004). A strong correlation is interpreted to indicate that stream chemistry is controlled by simple physical processes such as water dilution and evaporative concentration (Yuan and Miyamoto, 2004). The reduced correlation at Girvin suggests that there are other processes (e.g., reservoir mixing, groundwater baseflow, and bank storage) influencing the river chemistry. On the other hand, TDS flux is positively correlated with stream discharge at all the stations studied (Fig. 8). The correlation may be best described by a $\log$-linear equation (i.e., $\log (Q C)=a+b \log Q$ ). The slope $b$ of this log-linear equation varies from station to station, but is usually less than one (Table 5). The slope is a measure of the degree to which TDS concentration responds to change in discharge. The larger the slope, the less sensitive the TDS concentration. In the special case when $b=1$, TDS concentration is theoretically independent of stream discharge. There are four gauging stations with relatively large values of slope, such as Sumner, Acme, Brantley, and Langtry (Table 5). The spatial variations in the slope are related to changes in lithologic and hydrologic settings. For example, the relatively high values of slope at Sumner and Brantley are ascribed to facts: (1) that stream discharge is largely determined by reservoir operations or releases and (2) that the TDS concentration of reservoir outflow is determined primarily by the amount of inflow and reservoir storage (Inosako et al., 2005).

To further evaluate the mechanisms controlling water chemistry, major ion fluxes are plotted against discharge at two selected gauging stations of Artesia and Langtry (Figs. 9 and 10). At the two stations, $\mathrm{Na}$ and $\mathrm{Cl}$ fluxes have lower slope values than $\mathrm{Ca}$ and $\mathrm{SO}_{4}$ fluxes and the slope values of $\mathrm{HCO}_{3}$ are close to unity. This suggests that $\mathrm{Na}$ and $\mathrm{Cl}$ concentrations in the Pecos River are more sensitive to changes in stream discharge than $\mathrm{Ca}$ and $\mathrm{SO}_{4}$ concentrations. This may be partially explained by the differences in solubility of $\mathrm{NaCl}$ and $\mathrm{CaSO}_{4}$ and availability of $\mathrm{NaCl}$ and $\mathrm{CaSO}_{4}$-bearing minerals.
$\mathrm{NaCl}$ is much more soluble than $\mathrm{CaSO}_{4}$ so that may create $\mathrm{NaCl}$ deficit when persistent high flow occurs. This also explains the scattered nature of the $\mathrm{Na}$ and $\mathrm{Cl}$ fluxes against stream discharge (Figs. 9 and 10). However, the slope of $\mathrm{Na}, \mathrm{Ca}, \mathrm{Cl}$ and $\mathrm{SO}_{4}$ fluxes increases considerably at Langtry. As a result, the TDS concentration in the Pecos River near Langtry becomes less sensitive to local discharge, suggesting most of the dissolved salts are from upstream instead of locally derived.

The TDS concentration record of the lower Pecos River near Langtry displays a great deal of similarity with a stream discharge record at Girvin (Fig. 11). Maxima in the TDS concentration near Langtry usually coincided with maxima in stream discharge at Girvin. For example, the two prominent high-flow events occurring in the El Niño years of 1941 and 1987 were largely caused by snowmelt from winter storms in the upper basin. Both led to a huge amount of salt export to and high TDS concentration in the lower Pecos River. In particular, the annual stream discharge of 1941 ranked the second highest, but its TDS concentration near Langtry was the highest over the last 70 a. The TDS concentration in the lower Pecos River at Girvin usually exceeds $10000 \mathrm{mg} \mathrm{L}^{-1}$ which is substantially higher than that of local runoff $\left(\sim 300 \mathrm{mg} \mathrm{L}^{-1}\right)$. The TDS concentration in the lower Pecos River near Langtry is largely determined by the rate of salt export from the upper valley. The amount of salts present in the lower Pecos River is largely determined by the amount of stream discharge upstream, which appears to be related to the PDO (Fig. 6). This explains why the TDS concentration in the lower Pecos River tends to be positively correlated with the PDO index.

Table 5

Coefficients describing the log-linear correlation between stream discharge $\left(\mathrm{m}^{3} / \mathrm{s}\right)$ and TDS flux $(\mathrm{kg} / \mathrm{s})$ at the major gauging stations along the Pecos River

\begin{tabular}{llll}
\hline Station & $a$ & $b$ & $r$ \\
\hline Santa Rosa & 0.00 & 0.62 & 0.98 \\
Puerto de Luna & 0.56 & 0.49 & 0.88 \\
Sumner & 0.17 & 0.95 & 0.96 \\
Acme & 0.40 & 0.83 & 0.96 \\
Artesia & 0.70 & 0.67 & 0.92 \\
Brantley & 0.55 & 0.88 & 0.94 \\
Malaga & 0.70 & 0.67 & 0.96 \\
P.C. Crossing & 0.97 & 0.58 & 0.89 \\
Red Bluff & 0.94 & 0.65 & 0.89 \\
Girvin & 1.06 & 0.69 & 0.89 \\
Langtry & 0.35 & 0.91 & 0.88 \\
\hline
\end{tabular}



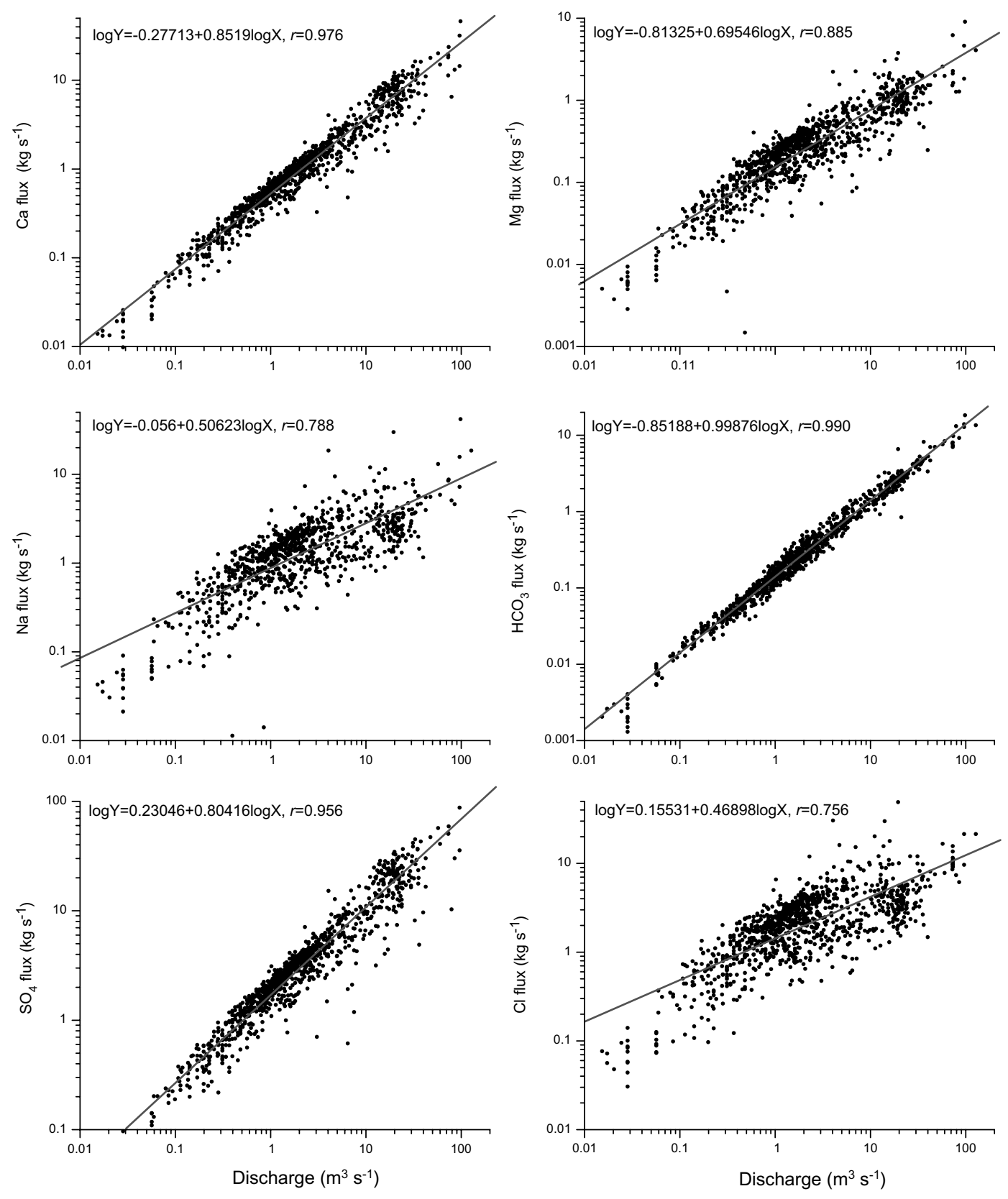

Fig. 9. Plots of major ion fluxes against discharge for the Artesia station.

However, there are some discrepancies between the PDO and TDS concentration in the lower Pecos River, especially in the late parts of the record (1975-1985 and 1992-1998) (Fig. 5). The inconsistencies are induced by a combination of variations in local monsoonal rainfall and changes in anthropogenic disturbances. The lower Pecos River occasionally received a fair amount of local freshwater that could dilute the TDS concentration consider- ably. For example, the prominent high-flow events in 1954, 1974 and 1997 led to three minima in the TDS concentration near Langtry (Fig. 11). The 1954 flood induced by Hurricane Alice was very phenomenal, with a peak discharge of $\sim 27000$ $\mathrm{m}^{3} / \mathrm{s}$ (IBWC, 1954). This unique flood not only destroyed the recording gauge installation and cableway near Comstock (IBWC, 1954), Texas, but also led to the lowest TDS concentration in 

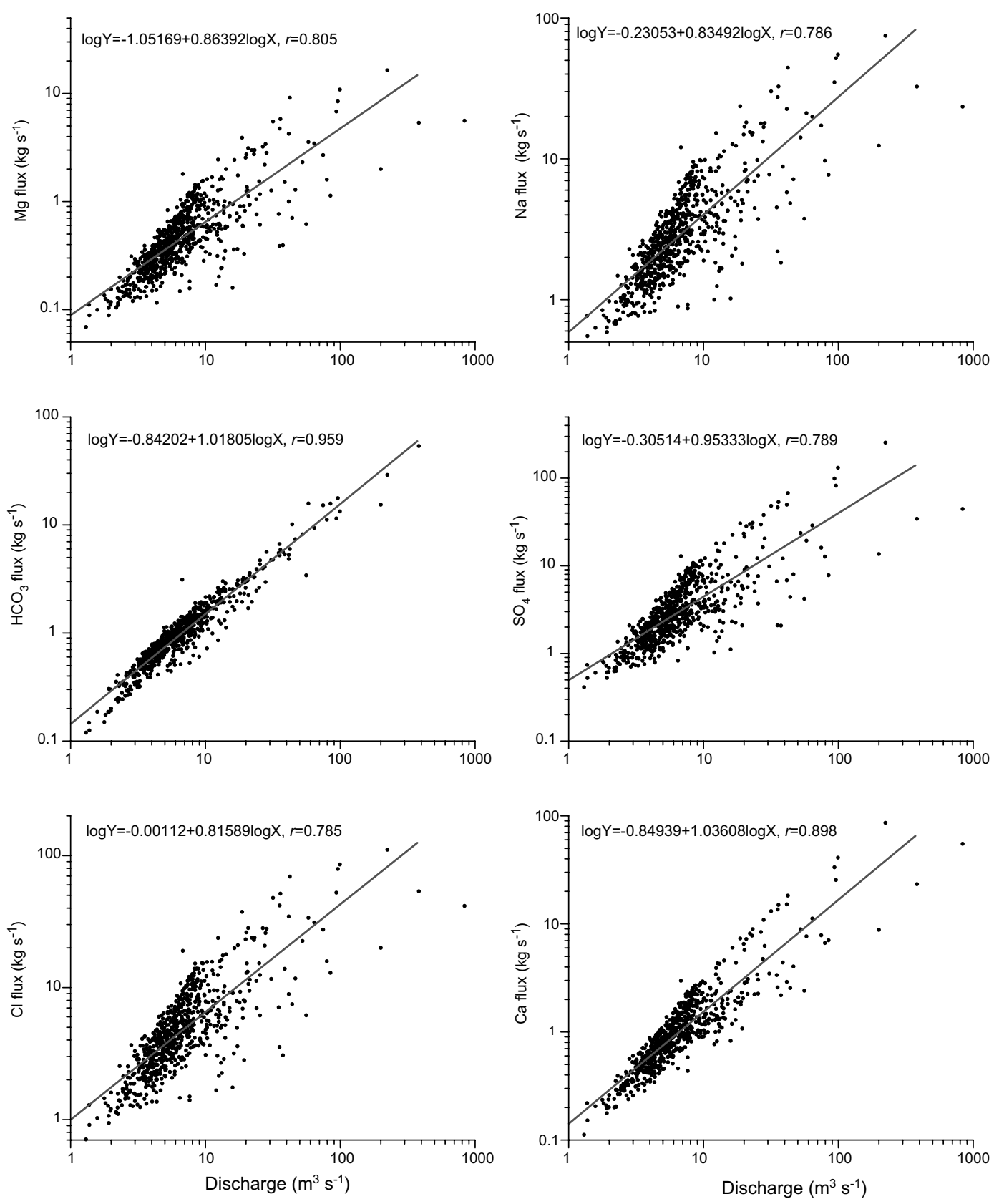

Fig. 10. Plots of major ion fluxes against discharge for the Langtry station.

the entire record. On the other hand, the rate of salt export has also been affected by changes in agricultural water withdrawal, reservoir storage, and saline water intrusion upstream. First, based on the historical data of irrigated land acreage for individual crop species planted from the USDA National Agricultural Statistics Service, there were rapid increases in irrigated land area in three counties (Eddy,
Chaves and De Baca) of New Mexico in the $1970 \mathrm{~s}$ (Fig. 12). Increases in irrigated land area are usually associated with increases in agricultural water withdrawal. Since the three counties are located within the Pecos River drainage, the relatively low TDS concentration in the lower Pecos between 1975 and 1985 appears to be related to substantial increases in irrigated land acreage upstream 


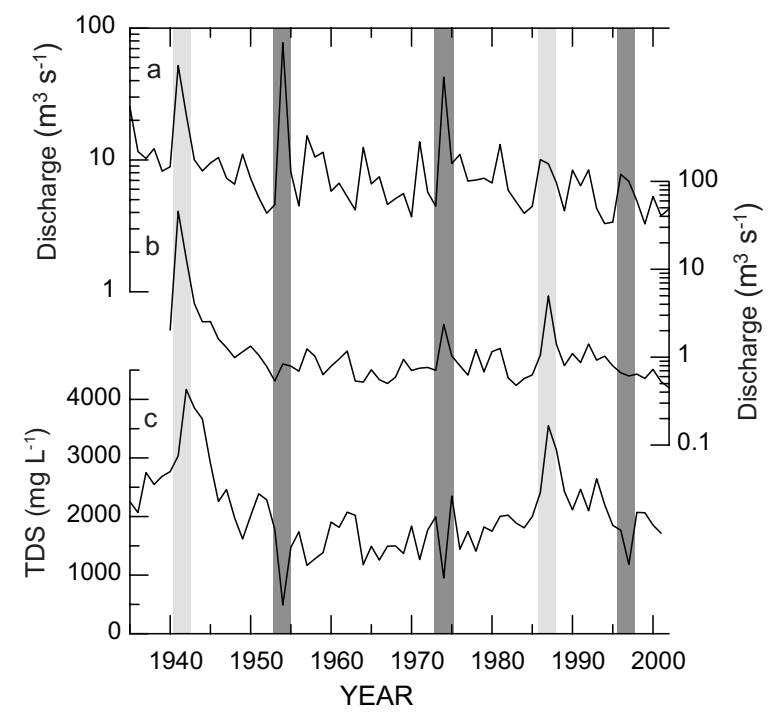

Fig. 11. Comparison of the Langtry TDS concentration with the discharge at Girvin and Langtry. (a) Annual discharge record near Langtry. (b) Annual discharge record at Girvin. (c) TDS concentration record of the Pecos River near Langtry (same data as presented in Fig. 5).

in middle 1970s. Second, increases in storage capacity of reservoirs upstream would temporarily reduce the rate of salt export. Many reservoirs were constructed in the late 1930s along the Pecos River (e.g., the Red Bluff, the Sumner and the Avalon Dams). Constructions of the Santa Rosa and Brantley dams in 1976 and 1988 increased the storage

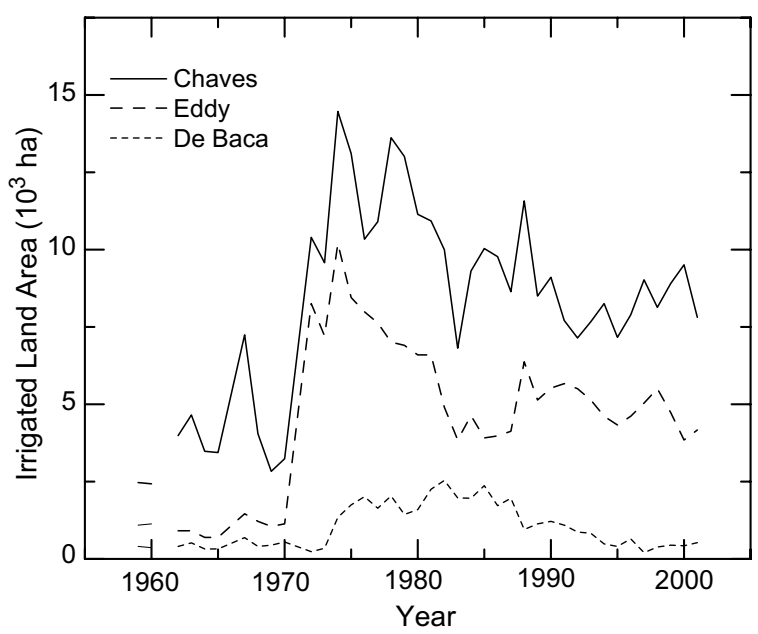

Fig. 12. Changes in irrigated cropland acreage from 3 counties (Eddy, Chaves, and De Baca) in New Mexico. Data were derived based on irrigated land acreage for individual crop species planted (original data from USDA-NASS Quick Stats). capacity of reservoirs. This appears to be a factor that led to the relatively low TDS concentration between 1975 and 1985 and between 1992 and 1998. Lastly, the US Geological Survey, in cooperation with the Pecos River Compact Commission, operated the Malaga Bend Salinity Alleviation Project between 1963 and 1976 to improve the quality of water that is delivered to Texas (Havens and Wilkins, 1980). As mentioned earlier, this project attempted to reduce the amount of saline groundwater intrusion near the Malaga Bend by pumping groundwater from the saline aquifer and discharging it into some playa lakes nearby. The operation might have temporarily alleviated stream salinity in the Pecos River. This project was terminated, because leakage from these lakes was identified.

\section{Summary and conclusions}

A study of a dryland river system has been conducted to develop the context of water chemistry changes on decadal to multi-decadal timescales. The results of this study indicate that change in water chemistry of the Pecos River is dictated primarily by large-scale climatic forcing, as represented by the PDO index. The Pecos River receives above average runoff from snowmelt in the Southern Rocky Mountains and exports above average dissolved salts to the lower basin when the PDO is in the positive (warm) phase and vice versa. On the other hand, there is a strong indication that the stream chemistry has also been affected by variations in local rainfall in the Edwards Plateau, irrigation water use, and reservoir impoundment, etc.

The results of the study could have broad implications for watershed management of dryland rivers in the western United States. Most of the dissolved salts are from dissolution of rock salts (e.g., gypsum, anhydrite and halite) in various geological formations in the upper valley. The rate of salt export is directly related to the amount of stream discharge upstream. Water diversions for agricultural practices are subject to salt accumulation and land degradation when poor drainage prevails. Increase in reservoir storage and/or irrigation water use reduces the rate of salt export from the Pecos River and temporarily alleviates salinity conditions of downstream water bodies (e.g., Amistad and Falcon Reservoirs) in the lower Rio Grande. However, salts stored or accumulated on irrigated lands will eventually be washed out when high-flow conditions persist. 


\section{Acknowledgements}

This work was financially supported by grants from US Environmental Protection Agency and USDA CSREES. Special thanks are due to N.A. Tchepkaia and two anonymous reviewers for their valuable comments and suggestions.

\section{References}

Armstrong, C.A., McMillion, L.G., 1961. Geology and groundwater resources of Pecos County, Texas. Texas Board of Water Engineers Bull. 6106, Austin, Texas.

Bean, R.T., 1949. Geology of the Roswell Artesian Basin, New Mexico, and Its Relation to the Hondo Reservoir. US Geol. Surv. Open-file Report; New Mexico State Engineer Technical Report 9, Santa Fe, New Mexico, p. 31.

Clark, G.M., Broshears, R.E., Hooper, R.P., Goolsby, D.A., 2003. Evaluating the influence of source basins on downstream water quality in the Mississippi River. J. Am. Water Resour. Assoc. 38, 803-818.

Davies, B.R., Thoms, M.C., Walker, K.F., O'Keefe, J.H., Gore, J.A., 1996. Dryland rivers: their ecology conservation and management. In: Calow, P., Petts, G.E. (Eds.), The Rivers Handbook: Hydrological and Ecological Principles. Blackwell Science Ltd, Cambridge, UK.

Durum, W.H., 1978. Historical profile of quality of water laboratories and activities, 1879-1973. US Geol. Surv. Open-file Report, pp. 78-432.

Fiedler, A.G., Nye, S.S., 1933. Geology and ground-water resources of the Roswell artesian basin, New Mexico, US Geol. Surv., Water-Supply Paper 639, 372.

Fishman, M.J., Friedman, L.C. (Eds.), 1989. Methods for determination of inorganic substances in water and fluvial sediments. US Geol. Surv. Tech. Water Resour.-Investig. TWRI 5-A1, Reston, VA.

Gershunov, A., Barnett, T.P., 1998. Interdecadal modulation of ENSO teleconnections. Bull. Am. Meteorol. Soc. 79, 2715-2726.

Grozier, R.U., Albert, H.W., Blakey, J.F., Hembree, C.H., 1966. Water-delivery and low-flow studies: Pecos River, Texas, quantity and quality, 1964 and 1965. US Geol. Surv. and Texas Water Development Board Report 22, Austin, Texas.

Gutzler, D.S., Kann, D.M., Thornbrugh, C., 2002. Modulation of ENSO-based long-lead outlooks of Southwestern U.S. winter precipitation by the Pacific Decadal Oscillation. Weather Forecast 17, 1163-1172.

Hale, W.E., Hughes, L.S., Cox, E.R., 1954. Possible improvement of quality of water of the Pecos River by diversion of brine at Malaga Bend, Eddy County, New Mexico, Pecos River Commission, Carlsbad, New Mexico.

Harrington, E.R., 1957. Sinkholes, bottomless lakes, and the Pecos River. Sci. Monthly 84, 302-308.

Harrington, M.W., 1885. Lost rivers. Science 6, 265-266.

Havens, J.S., Wilkins, D.W., 1980. Experimental salinity alleviation at Malaga Bend of the Pecos River, Eddy County, New Mexico. US Geol. Surv. Water-Resour. Investig., 80-84.

Hooper, R.P., Aulenbach, T., Kelly, V.J., 2001. The national stream quality accounting network: A flux-based approach to monitoring the water quality of large rivers. Hydrol. Proc. 15, 1089-1106.
Howard, C.S., White, W.F., 1938. Chemical character of Pecos River in New Mexico. Biennial Report of the State Engineer of New Mexico, Santa Fe, New Mexico.

IBWC, 1954. Flow of the Rio Grande and related data from Elephant Butte Dam, New Mexico to the Gulf of Mexico. International Boundary and Water Commission United States and Mexico, El Paso, Texas.

IBWC, 1967. Flow of the Rio Grande and related data from Elephant Butte Dam, New Mexico to the Gulf of Mexico. International Boundary and Water Commission United States and Mexico, El Paso, Texas.

Inosako, K., Yuan, F., Miyamoto, S., 2005. Simple methods for estimating outflow salinity from inflow and reservoir storage. Agric. Water Manage. 82, 411-420.

Knighton, A.D., Nanson, G.C., 1997. Distinctiveness, diversity and uniqueness in arid zone river systems. In: Thomas, D.S.G. (Ed.), Arid Zone Geomorphology: Process, Form, and Change in Drylands. Wiley, Chichester, pp. 185-203.

Lasaga, A.C., Soler, J.M., Ganor, J., Burch, T.E., Nagy, K.L., 1994. Chemical weathering rate laws and global geochemical cycles. Geochim. Cosmochim. Acta 58, 23612386.

Linsley, B.K., Wellington, G.M., Schrag, D.P., 2000. Decadal sea surface temperature variability in the subtropical south pacific from 1726 to 1997 A.D. Science 290, 1145-1148.

Mantua, N.J., Francis, R.C., Hare, S.R., Zhang, Y., Wallace, J.M., 1997. A Pacific interdecadal climate oscillation with impacts on salmon production. Bull. Am. Meteorol. Soc. 78, 1069-1079.

McLemore, V.T., 1989. Santa Rosa Lake State Park. New Mexico Geol. 11, 8-10.

McLemore, V.T., 1999. Bottomless Lakes State Park. New Mexico Geol. 21, 51-55.

McMahon, T.A., 1979. Hydrological characteristics of arid zones. In: The Hydrology of Areas of Low Precipitation. Proc. Canberra Symp, December 1979, pp. 105-123.

Ogilbee, W., Wesselman, J.B., 1962. Geology and ground-water resources of Reeves County, Texas. Water Commun. Bull. 6214, Austin, Texas.

Rasmussen, E.M., Wallace, J.M., 1983. Meteorological aspects of the El Niño/Southern Oscillation. Science, 222.

Riehl, H., Alaka, M.A., Jordan, C.L., Renard, R.J., 1954. The jet stream. Meteorol. Monogr. 2, 23-47.

Sidwell, R., 1941. Sediments of Pecos River, New Mexico. J. Sed. Pet. 11, 80-84.

Sidwell, R., Warn, G.F., 1953. Pennsylvanian and related sediments of upper Pecos valley, New Mexico. Am. Assoc. Petrol. Geol. Bull. 37, 975-1013.

Slade, R.M.J., Bentley, J.T., Michaud, D., 2002. Results of Stream Gain-Loss Studies in Texas, With Emphasis on Gains From and Losses to Major and Minor Aquifers, Texas, 2000. US Geol. Surv. - Open-File Report 02-068, Austin, Texas, p. 136.

Theis, C.V., 1965. Ground water in southwestern region. In: Young, A., Galley, J.E. (Eds.), Fluids in Subsurface Environments, A Symposium. American Association of Petroleum Geologists, Tulsa, Okla., pp. 327-341.

Thomas, H.E. 1963. Causes of depletion of the Pecos River in New Mexico, US Geological Survey Water-Supply Paper 1619-G, Washington, DC, pp.1-14.

Van Denburgh, A.S., Feth, J.H., 1965. Solute erosion and chloride balance in selected river basins of the western conterminous United States. Water Resour. Res. 1, 537541. 
Walling, D.E., Webb, B.W., 1983. The dissolved load of rivers: global overview. In: Webb, B.W. (Ed.), Dissolved Loads of Rivers and Surface Water Quality. Internat. Assoc. Hydrol. Sci. (IAHS) Publ. No. 141, Wallingford, Oxfordshire, UK.

Ware, D.M., Thomson, R.E., 2000. Interannual to multidecadal timescale climate variations in the Northeast Pacific. J. Clim. $13,3209-3220$.
Yuan, F., Miyamoto, S., 2004. Influence of the Pacific Decadal Oscillation on hydrochemistry of the Rio Grande, USA and Mexico. Geochem. Geophys. Geosyst. 5, 1-10.

Yuan, F., Miyamoto, S., 2005. Dominant processes controlling water chemistry of the Pecos River in American Southwest. Geophys. Res. Lett. 32, 1-4. 